\title{
Hepatitis B Virus Infection among Prison Inmates in Borno State: Determination of Prevalence of Surface Antigen (HBsAg) and Possible Risk Factors of Disease
}

\author{
Lawan $\mathrm{S}^{2}$, Gimba $\mathrm{SN}^{2}$, Elyuguda $\mathrm{AD}^{2}$, Sabo $\mathrm{H}^{1}$ and \\ Dadile HM ${ }^{1}$ \\ ${ }^{1}$ Department of Basic Nursing, Shehu Sule College of \\ Nursing and Midwifery Damaturu, Nigeria \\ ${ }^{2}$ Department of Veterinary Microbiology, University of \\ Maiduguri, Faculty of Veterinary Medicine, Nigeria \\ *Correspondling author: Saleh Nadabo Gimba, \\ Department of Basic Nursing, Shehu Sule College of \\ Nursing and Midwifery Damaturu, Nigeria
}

Received: April 12, 2021; Accepted: May 03, 2021; Published: May 10, 2021

\begin{abstract}
An epidemiological study on hepatitis B virus infection among prison inmates in Borno state, Nigeria, was carried out using a questionnaire survey to determine the possible risk factors of the disease and serological method [using an Enzyme Linked Immunosorbent Assay (ELISA)] to determine the prevalence of hepatitis B surface antigen (HBsAg) among the inmates. The study was conducted in correctional facilities in Maiduguri, Biu and Bama local government area of Borno State. Out of a total of 300 sera tested, $49(16.3 \%)$ had detectable ELISA antibody to HBsAg. A significant difference $(p<0.001)$ in seroprevalence of $\mathrm{HBsAg}$ among inmates of different educational qualifications was observed and those with higher education had the highest prevalence $(20.9 \%)$. Although there was no significant difference in prevalence of $\mathrm{HBsAg}$ among the different age groups, the age group 60-69 years had the highest infection rate (33.3\%). Homosexuality and duration of stay in prison are shown to be significantly associated with $\mathrm{HBsAg}$ infection $(P<0.05)$ among inmates. A significant gender difference was noted among inmates with the males $(16.1 \%)$ having higher prevalence when compared with females (20.0\%). Analysis of spatial distribution of prevalence of HBsAg showed that Maiduguri prison had $(20.5 \%)$, followed by Biu prison (12.7\%) and Bama prison (6.7\%) and there was significant difference $(P<0.05)$ in prevalence between prisons. There was no significant $(P>0.05)$ association of prevalence of $\mathrm{HBsAg}$ with marital status or occupation of prison inmates. In conclusion, hepatitis b virus infection was found to be prevalent among prison inmates in Borno state with homosexuality and duration of stay in prison as risk factors.
\end{abstract}

\section{Background}

Hepatitis B infection is an acute infection of liver in which the liver cells are inflamed [1]. Viral hepatitis causes considerable mortality both from acute infection and chronic disease conditions and ranks among the ten top killer diseases world-wide [2]. Hepatitis virus lives in the blood and other body fluids and is transmitted from person to person through unprotected sexual intercourse with an infected person, sharing infected needles, or other sharp objects that break the skin [3]. Hepatitis B Virus (HBV) infection is worldwide and a serious global health problem which accounts for over two billion infected cases and 400 million suffering from chronic infections worldwide $[4,5]$. It has been reported that hepatitis B related illnesses cause an estimated 1-2 million deaths per year worldwide [2].

The HBV infection varies widely across the world from high ( $>8$ \%) in Africa, Asia and the Western Pacific, intermediate (2-7.9 \%) in Southern and Eastern Europe to low $(<2 \%)$ in Western Europe, North America and Australia [2,6]. Nigeria, a tropical country, is highly endemic for HBV infection and about $75 \%$ of its population is likely to have been exposed to the virus at one time or the other in their lives [7]. The prevalence rate of HBV in Nigeria is high and 19 million Nigerians are infected with the virus [8] and have reached hyper-endemic levels with the sero-prevalence of Hepatitis B surface antigen estimated to range from 10 to $40 \%[5,9]$. Hepatitis
$B$ virus is a blood borne pathogen, which is efficiently transmitted by percutaneous or per mucosal exposure to infectious blood or other body fluids [10]. Hepatitis B virus is present in the blood, saliva, semen, vaginal secretions, menstrual blood, and to a lesser extent, perspiration, breast milk, tears, and urine of infected individuals [11]. The routes of transmission vary according to the endemicity of the $\mathrm{HBV}$ infection. In areas of high endemicity, perinatal transmission is the main route of transmission, whereas in areas of low endemicity, sexual contact amongst high-risk adults is predominant [12].

Unlike in Europe and America, there are limited published data on HBV infections among prison inmates in Nigeria and the rest of Africa despite its tremendous importance in public health policy formulation [13]. There is currently no periodic national survey for HBV in either the Nigerian general population or prison inmates; however, prisoners worldwide are at high risk of contracting $\mathrm{HBV}$, especially those who engage in high-risk behaviours such as intravenous drug use, sharing of nail cutter, clipper and or homosexual activities [13]. Prisoners are therefore potential reservoirs of infection to the uninfected entrants and the general non-incarcerated population upon regaining freedom.

In this study, a cross-sectional survey was carried out in selected correctional facilities in Borno State, Nigeria, to determine, the seroprevalence of hepatitis $\mathrm{B}$ surface antigen and possible risk factors
J Hepat Res - Volume 6 Issue 1 - 2021

ISSN : 2381-9057 | www.austinpublishinggroup.com

Gimba et al. (C) All rights are reserved
Citation: Lawan S, Gimba SN, Elyuguda AD, Sabo H and Dadile HM. Hepatitis B Virus Infection among Prison Inmates in Borno State: Determination of Prevalence of Surface Antigen (HBsAg) and Possible Risk Factors of Disease. J Hepat Res. 2021; 6(1): 1041. 
associated with this silent and deadly viral infection.

\section{Materials and Methods}

\section{Study area}

The study was conducted in correctional facilities in Maiduguri, Biu and Bama local government areas of Borno state. Borno state lies between latitude $100 \mathrm{~N}$ and $130 \mathrm{~N}$ and longitude $120 \mathrm{E}$ and $150 \mathrm{E}$. The state has an area of about $69,436 \mathrm{~km}^{2}$ [14]. The state is located in the North eastern part of Nigeria, and has an estimated population of 4.2 million people [15]. Borno state has a hot climate with average peak daily temperature ranging between $34^{\circ} \mathrm{C}$ and $40^{\circ} \mathrm{C}$ especially in April and May. The rainy season lasts from June to September in the North which has a Sahelian vegetation and May to October in the South with Sudan vegetation $[16,17]$.

\section{Study population and sample size determination}

Three hundred prison inmates were employed (age ranged 18 to 69 years) comprising 285 males and 15 females for this study from the total number of five hundred and seventy nine(579) inmates, out of which 404 from maximum security prison, 97 from Biu prison and 78 from Bama prison respectively in Borno state. The period of study was conducted between November through January 2012/2013. The previous prevalence used for this study was $11.6 \%$ by Harry et al. The sample size was obtained using the formula for Sample Size $=$ n/1-(n/ population size).

Where $\mathrm{n}=\mathrm{z}^{2} \mathrm{pq} / \mathrm{d}^{2}$;

$\mathrm{n}=$ number of participants required in the survey,

$\mathrm{Z}=$ normal standard deviation at 1.96 (which corresponds to $95 \%$ confidence interval, $\mathrm{P}=$ prevalence of Hepatitis B surface antigen from previous study;

$\mathrm{q}=1-\mathrm{p}$ and $\mathrm{d}=$ degree of accuracy/precision expected set at 0.05 [18].

\section{Ethical clearance}

The study was approved by the State Ministry of Health Maiduguri, Borno state, in accordance with the code of ethics for biomedical research involving human subjects. Official consent of the State's highest prison authority, the State Comptroller of prisons, was also obtained.

\section{Questionnaire survey}

Structured open ended questionnaires were prepared and administered on the spot to each of the participating inmates (Appendix A). The inmates were asked about their socio-demographic details including prison identification number, sex, age, ethnicity, residence, educational qualification, occupation and marital status. Information was also asked about the mode of imprisonment and jail term and exposure to risk factors associated with blood transfusion, intravenous drug use as well as history of sexual behaviour including sexual orientation, number of sexual partners, homosexuality and history of sexually transmitted diseases and sharing of clippers and sharp objects. Information on vaccination against $\mathrm{HBV}$ infection was also obtained from the inmates.

\section{Serum sample}

Venous blood samples were collected from three hundred participants using a sterile $5 \mathrm{ml}$ syringe and needle. The samples were collected into sterilised plain vacutainer tubes and conveyed to laboratory for serum separation. The blood samples were kept at room temperature to clot. Serum samples were harvested from the clotted blood by centrifuging at 2,000 revolutions per minutes for 10 minutes. The harvested serum was put into cryotubes and stored at $-20^{\circ} \mathrm{C}$ until tested.

\section{Assay of serum samples for HBsAg}

The serum samples were analysed for the presence of HBsAg using the sandwich Enzyme Linked Immunosorbent Assay (ELISA) [Monolisa ${ }^{\mathrm{TM}}$ HBsAg ULTRA Bio-Rad-F 92430-Marnes la Coquette, LOT 2J0152, France]. The Monolisa ${ }^{\mathrm{TM}}$ HBsAg ULTRA has an analytical sensitivity of $0.2 \mathrm{ng} / \mathrm{ml}$; assay sensitivity of $99.98 \%$, and specificity of $100 \%$. The test is based on the principle of the sandwich ELISA using monoclonal antibodies and polyclonal antibodies selected for their ability to bind themselves to the various subtypes of HBsAg in serum, which is a marker of acute HBV infection. The test was conducted following the manufacturer's instructions and the microtitre plates were read at a wavelength of $450 \mathrm{~nm}$, using ELISA reader (E-max-reader, precision microtitre plate reader MDS -Analytical technique USA).

\section{Principle of sandwich ELISA}

Antibodies sandwich ELISA may be most useful in detecting antigen because they are frequently between 2 and 5 times more sensitive than those in which antigen is directly bound to the solid phase. To detect antigen, the wells of microtiter plates are coated with specific (captured) antibody followed by incubation with test solutions containing antigen. Unbound antigen is washed out and an antigen specific antibody conjugated enzyme (i.e. developing reagent) is added, followed by incubation. Enzyme labelled antibody can be produced in the same animal that produced passively adsorbed antibody, or from a different species immunised with the same antigen that is captured. Unbound conjugate is washed out and substrate is added. After incubation, the degree of substrate hydrolysis is measured. The amount of substrate hydrolysed is proportional to the amount of antigen in the test solution.

\section{Procedure of sandwich ELISA (Monolisa ${ }^{\mathrm{TM}}$ HBsAg ULTRA)}

The procedure of the sandwich ELISA was followed in accordance with the manufacturer's instruction. Briefly, $100 \mu \mathrm{l}$ of negative control was added into a selected wells and addition of $100 \mu$ of positive control into appropriate pre-coated wells with monoclonal antibody. This was followed by the addition of $100 \mu \mathrm{l}$ of the test sera into the remaining wells. Fifty microlitres $(50 \mu \mathrm{l})$ of conjugate solution consist of (conjugate diluent- bovine immunoglobulin and mouse immunoglobulin, and conjugate-consist of mouse monoclonal anti HBsAg antibodies and goat polyclonal antibodies) was then dispensed into all the wells. The plate was then covered with a new adhesive film and incubated for 1 hour 30 minutes at $37^{\circ} \mathrm{C}$. After the incubation the plate was emptied by aspiration and washed for a minimum of 5 times. The plate was dried by turning them upside down on absorbent paper. One hundred microlitres $(100 \mu \mathrm{l})$ of freshly prepared substrate solution consist of (substrate buffer-citric acid and sodium acetate; containing $\mathrm{H} 2 \mathrm{O} 2$ and DMSO and chromogen pink coloured solution; containing TMB), was dispensed into all the wells and incubated in the dark for 30 minutes at room temperature (16- 
$30^{\circ} \mathrm{C}$ ). The reaction was stopped by the addition of $100 \mu \mathrm{l}$ of stopping solution (1N Sulphuric acid).

\section{Data analysis}

Data obtained from the study were analysed using Statistical Package for Social Sciences (SPSS) Version 16 software. Chi-square and Fisher's exact test were used to perform categorical comparison and level of significance at $95 \%$ confidence interval. P-value less than or equal to $(\mathrm{P} \leq 0.05)$ was considered statistically significant.

\section{Results}

Hundred (100\%) response rates were recorded for the questionnaire survey. Results of the seroepidemiological survey for HBsAg among prison inmates in Borno state showed an overall prevalence rate of $49 / 300(16.3 \%)$ (Table 1) The gender distribution of the HBsAg positive reactors indicated 46/285 (16.1\%) males and $3 / 15(20.0 \%)$ females. No significant difference $(\mathrm{p}>0.05)$ was observed in the gender distribution of HBsAg in prison inmates. Gender was therefore not a risk factor in this study. Analysis of the age distribution of seroprevalence of HBsAg infection among the prison inmates revealed that the age groups 53-59 and 60-69 years had the highest prevalence rates of $28.6 \%$ and $33.3 \%$ respectively, followed by the age groups $18-24$ (15.0\%), 25-31 (15.4\%), 32-38 (19.0\%) and $39-45$ (18.2\%) years and the least was $46-52$ years (8.3\%) (Table 2$)$. There was no significant difference $(\mathrm{p}>0.05)$ in the prevalence of HBV infection between the different age groups. Figure 1 below represents the frequency distribution of ELISA Optical Density (OD) values of the HBsAg positive sera from prison inmates. Majority (85.7\%) of the positive samples reacted with low to intermediate $\mathrm{OD}$ values (1-1.5, 1.6-2.0, 2.1-2.5) as compared to the $14.3 \%$ with high OD values (2.6-3.5). Optical density values that are equal to or greater than 1.0 were considered positive. Significant difference $(\mathrm{P}<0.05)$ was noted in the prevalence of HBsAg among the different ethnic groups of prison inmates studied (Table 3). The distribution of the prevalence in decreasing order among the different ethnic groups was as follows: Marghi (32.0\%), Hausa (23.9\%), Michika and Kanakuru

Table 1: Sex distribution of HBsAg among prison inmates in Borno state.

\begin{tabular}{|c|c|c|}
\hline Gender & Total No Tested & No (\%) Positive \\
\hline Male & 285 & $46(16.1)$ \\
\hline Female & 15 & $3(20.0)$ \\
\hline Total & 300 & $49(16.3)$ \\
\hline
\end{tabular}

$P$ value: 0.7189

Table 2: Age distribution of prevalence of HBsAg in Prison inmates in Borno state.

\begin{tabular}{|c|c|c|}
\hline Age (Years) & Total No Tested & No (\%) positive \\
\hline $18-24$ & 80 & $12(15.0)$ \\
\hline $25-31$ & 104 & $16(15.4)$ \\
\hline $32-38$ & 42 & $8(19.0)$ \\
\hline $39-45$ & 33 & $6(18.2)$ \\
\hline $46-52$ & 24 & $2(8.3)$ \\
\hline $53-59$ & 14 & $4(28.6)$ \\
\hline $60-69$ & 3 & $1(33.3)$ \\
\hline Total & 300 & $49(16.3)$ \\
\hline
\end{tabular}

$P$ value: 0.7072

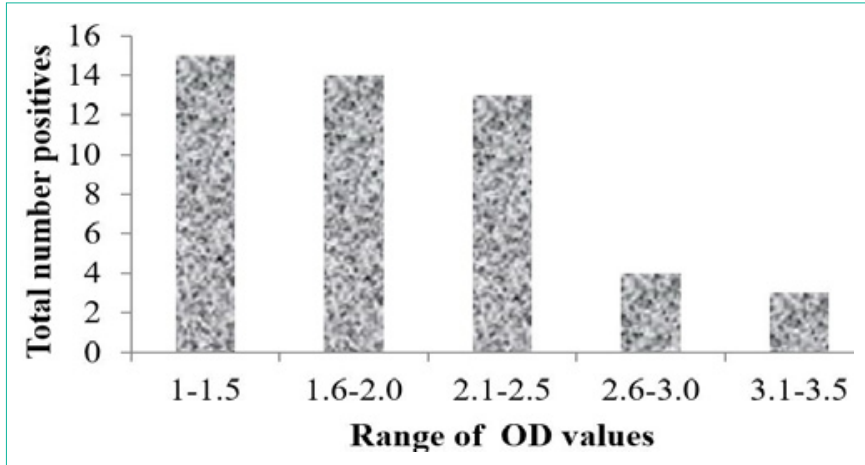

Figure 1: Range of Optical Density (OD) values of the HBsAg positive $(\mathrm{N}=49)$ individuals among prison inmates in Borno State.

Table 3: Distribution of prevalence of HBsAg among prison inmates based on their ethnicity in Borno state.

\begin{tabular}{|c|c|c|}
\hline Tribe & Total No Tested & No (\%) positive_ \\
\hline Kanuri & 46 & $6(13.0)$ \\
\hline Hausa & 46 & $11(23.9)$ \\
\hline Shuwa Arab & 19 & $3(15.8)$ \\
\hline Marghi & 25 & $8(32.0)$ \\
\hline Gwoza & 6 & $1(16.7)$ \\
\hline Babur & 49 & $5(10.2)$ \\
\hline Michika & 5 & $1(20.0)$ \\
\hline Kanakuru & 5 & $1(20.0)$ \\
\hline Fulani & 44 & $3(6.8)$ \\
\hline Others & 55 & $10(18.2)$ \\
\hline Total & 300 & $49(16.3)$ \\
\hline
\end{tabular}

$P$ value: 0.02563 , "Yoruba, Igbo, Igala, Karekare.

Table 4: Distribution of prevalence of HBsAg among prison inmates based on their marital status in Borno State.

\begin{tabular}{|c|c|c|}
\hline Status & Total No Tested & No (\%) positive \\
\hline Single & 145 & $23(15.7)$ \\
\hline Married & 152 & $25(16.5)$ \\
\hline Divorcee & 0 & 0 \\
\hline Separated & 3 & $1(33.3)$ \\
\hline Widow/Widower & 0 & 0 \\
\hline Total & 300 & $49(16.3)$ \\
\hline
\end{tabular}

$P$ value: 0.7191

(20.0\% each), others (Yoruba, Igbo, Igala, Karekare) (18.2\%), Gwoza (16.7\%), Shuwa Arab (15.8\%), Kanuri (13.0\%), Babur-bura (10.2\%) and Fulani (6.0\%) (Table 3).

The prevalence of HBsAg based on marital status among prison inmates in Borno State is presented in Table 4. There was no significant difference in the prevalence of HBsAg based on the marital status of the inmates. Inmates that were separated showed higher prevalence rate $1 / 3(33.3 \%)$ than those that were single $23 / 145(15.9 \%)$ and married 25/152 (16.4\%) while none was found to be positive among divorcees and widows. However, significant difference $(\mathrm{p}<0.05)$ in prevalence of HBsAg was observed among the prison inmates based on their educational backgrounds (Table 5). Highest prevalence of HBsAg [5/17 (29.4\%)] was observed among those with higher 
Table 5: Distribution of prevalence of HBsAg based on the educational background of Prison inmates in Borno state.

\begin{tabular}{|c|c|c|}
\hline Level & Total No Tested & No (\%) positive \\
\hline Tsangaya & 70 & $15(21.4)$ \\
\hline Primary school & 47 & $5(10.6)$ \\
\hline Secondary school & 82 & $17(20.7)$ \\
\hline Higher institution & 17 & $5(29.4)$ \\
\hline None $^{*}$ & 84 & $7(8.3)$ \\
\hline Total $^{*}$ & 300 & $49(16.3)$ \\
\hline
\end{tabular}

$P$ value: 0.0464 *No level of education attended.

Table 6: Distribution of prevalence of HBsAg based on occupation of prison inmates before their incarceration.

\begin{tabular}{|c|c|c|}
\hline Occupation & Total No Tested & No (\%) positive \\
\hline Traders & 44 & $8(18.2)$ \\
\hline Farmers & 92 & $12(13.0)$ \\
\hline Students & 15 & $3(20.0)$ \\
\hline Labourers & 63 & $11(17.5)$ \\
\hline Drivers & 21 & $0(0)$ \\
\hline Law enforcement agents & 41 & $8(19.5)$ \\
\hline Civil servants & 6 & $3(50.0)$ \\
\hline Business men & 18 & $4(22.2)$ \\
\hline Total & 300 & $49(16.3)$ \\
\hline
\end{tabular}

$P$ value: 0.03049 .

Table 7: Distribution of prevalence of HBsAg among Prison inmates based on the location of their correctional facilities in Borno State.

\begin{tabular}{|c|c|c|}
\hline Location & Total No Tested & No (\%) Positive \\
\hline Maiduguri & 176 & $36(20.5)$ \\
\hline Biu & 79 & $10(12.7)$ \\
\hline Bama & 45 & $3(6.7)$ \\
\hline Total & 300 & $49(16.3)$ \\
\hline
\end{tabular}

$P$ value: 0.0487 .

education, followed in decreasing order of prevalence by those with tsangaya (is a type of non-formal education practiced by Muslims) education 15/70 (21.4\%), secondary school education $17 / 82$ (20.7), primary education 5/47 (10.6) and uneducated 7/84 (8.3\%). Significant difference $(\mathrm{P}<0.05)$ in prevalence of $\mathrm{HBsAg}$ was also noted among inmates based on their occupations before they were incarcerated. Those in civil service were most infected [3/6 (50.0\%)], followed in decreasing order of prevalence by businessmen $4 / 18$ (22.2\%), students $3 / 15$ (20.0\%), law enforcement agents 8/41 (19.5\%), traders $8 / 44(18.2 \%)$, labourers 11/63 (17.5\%), farmers 12/92 (13.0\%) and drivers $0 / 21(0 \%)$ (Table 6).

Significant difference $(\mathrm{P}<0.05)$ in prevalence of $\mathrm{HBsAg}$ was also observed among inmates in different correctional facilities in the study locations. Maiduguri prison had the highest prevalence of $36 / 176$ (20.5\%), followed by Biu prison 10/79 (12.0\%) and least in Bama prison 3/45 (6.7\%) (Table 7). The distribution of prevalence of HBsAg among prison inmates in relation to other risk factors is presented in Table 4.8. Homosexuality and length of stay in prison were significant $(\mathrm{p}<0.05)$ risk factors for HBV infections among the prison inmates in Borno State.
Table 8: Prevalence of HBsAg among prison inmates in relation to identified risk factors in Borno State.

\begin{tabular}{|c|c|c|c|c|c|c|}
\hline $\begin{array}{c}\text { Risk } \\
\text { factor }\end{array}$ & $\begin{array}{c}\text { No } \\
\text { Tested }\end{array}$ & $\begin{array}{c}\text { No (\%) } \\
\text { positive }\end{array}$ & RR & 95\% C.I & $x^{2}$ & p-value \\
\hline \multicolumn{7}{|c|}{ Blood Transfusion } \\
\hline Yes & 16 & $4(25)$ & 1.578 & $0.6478-3.843$ & 0.95 & 0.3079 \\
\hline No & 284 & $45(15.8)$ & & & & \\
\hline \multicolumn{7}{|c|}{ Intravenous drug use } \\
\hline Yes & 63 & $9(14.3)$ & 0.8464 & $0.4341-1.650$ & 0.2 & 0.7046 \\
\hline No & 237 & 40 (16.9) & & & & \\
\hline
\end{tabular}

\section{Use of sharp objects}

\begin{tabular}{|c|c|c|c|c|c|c|}
\hline Yes & 261 & $45(17.2)$ & 1.681 & $0.6399-4.416$ & 0.065 & 0.3559 \\
\hline No & 39 & $4(10.2)$ & & & & \\
\hline \multicolumn{7}{|c|}{ Homosexuality } \\
\hline Yes & 97 & $39(40.2)$ & 8.162 & $4.255-15.656$ & 39.9 & 0.0001 \\
\hline No & 203 & $10(4.9)$ & & & & \\
\hline
\end{tabular}

No of sex partner (s)

\begin{tabular}{|c|c|c|c|c|c|c|}
\hline 1 & 55 & $5(9.1)$ & 0.5062 & $0.2104-1.218$ & 2.5 & 0.1558 \\
\hline$\geq 2$ & 245 & $44(17.9)$ & & & & \\
\hline \multicolumn{7}{|c|}{ Knowledge of mode of transmission } \\
\hline Yes & 11 & $2(18.2)$ & 1.118 & $0.3106-4.025$ & 0.037 & 0.6968 \\
\hline No & 289 & $47(16.3)$ & & & & \\
\hline
\end{tabular}

Sexually transmitted infection

\begin{tabular}{|c|c|c|c|c|c|c|}
\hline Yes & 200 & $31(15.5)$ & 0.8611 & $0.5074-1.462$ & 0.82 & 0.6204 \\
\hline No & 100 & $18(18.0)$ & & & & \\
\hline Duration of stay in prison & & & \\
\hline $0-<2$ yrs. & 207 & $17(8.3)$ & 0.2387 & $\begin{array}{c}0.1398- \\
0.4076\end{array}$ & 32.17 & 0.0001 \\
\hline$\geq 2$ yrs. & 93 & $32(34.4)$ & & & & \\
\hline
\end{tabular}

$\mathrm{P}<0.05=$ Significant.

\section{Discussion}

Prison is a place used in holding a wide spectrum of persons, including persons awaiting arraignment, trial, conviction, sentencing or serving short sentences or convicted criminals [19]. It may serve as incubators where people of unknown health status, could spread infectious diseases [20]. In this study a prevalence rate of $16.3 \%$ of HBsAg was observed among prison inmates in Borno State. This result is lower than the prevalence rate of $23 \%$ previously reported among prison inmates in Nasarawa State [13]. The disparity could be due to differences in the geographical location of the two studies and relative abundance of risk factors such as homosexuality, Intravenous drug used and sharing of sharp objects. On the other hand the result of this study is higher than the 6.7\% observed among inmates in Lagos [21]. This could be due to the fact that inmates in Lagos are better informed about the practice of preventive measures against HBV infections. In sub-Saharan Africa the endemic rates of $\mathrm{HBV}$ infection are highest, with as many as $20 \%$ of the population being infected. In North America and Western Europe the infection is not common (0.1-0.2 \%) [22]. Nigeria, a tropical country, has been documented as highly endemic for $\mathrm{HBV}$ infection and about $75 \%$ of its population is likely to have been exposed to the virus at one time or the other in their lives [7]. The prevalence rate in Nigeria is high and 19 million Nigerians 
are considered to be infected with HBV [8] and have reached hyperendemic levels with the seroprevalence of HBsAg estimated to range from 10 to $40 \%$ [5]. Besides, the prevalence rate obtained in the present study is lower than the $25.5 \%$ prevalence observed in Ghanaian prisons [23]. This may be due to the difference in population size between the two studies and the possibility of risky behavioral practices among the Ghanaian prison inmates. The $16.3 \%$ prevalence observed in this study is also lower than the $20.0 \%$ observed in Greece prisons [24]. The possible reasons for this difference may be due to difference in geographical locations and relative risk behaviours of the prison inmates in the two studies. Conversely, the prevalence rate of HBsAg observed in this study is higher than that $(0.9 \%)$ reported for prison inmates in USA [19]. This may possibly be because the Americans have institutionalized infection control measures and implemented harm reduction intervention in their prisons. The present study also revealed higher prevalence of HBsAg than the $13.1 \%$ reported among prison inmates in Taiwan [25]. The only possible risk factor reported in the Taiwan study was the practicing of tattooing. However, the result of the current study is similar to the findings of Abdulelah [26] who reported an overall prevalence rate of $16.7 \%$ among the general population in Saudi Arabia. The prevalence rate of $16.3 \%$ observed in this study is higher than the $11.6 \%$ reported among pregnant women in Maiduguri Nigeria [27] and the 8.22\% HBV carrier rates reported among the general populace in Nigeria [28]. The observed difference between the results of this study and the previous ones could be as a result of the high risk behavioural practices (homosexuality and long stay in the prison) of inmates in the correctional facilities in this study. The current study has also revealed a gender difference in the prevalence of $\mathrm{HBV}$ infection. Females had higher seroprevalence rate of $20.0 \%$ than the male (16.1\%). This tally with the findings of Taura et al. [29] who found that, females had the higher prevalence of HBsAg. This as a result of large sample size and engaged themselves in practicing of illegal behaviors such as Male having sex with Male and heterosexual. However, the results of the present study disagreed with the reports of Ataie et al. [10], Abdul et al. [20], Lawal et al. [30], Bukbuk et al. [12], who all reported that males had higher percentage prevalence of HBsAg than the females. The difference observed could be attributed to the sample size and the sociocultural backgrounds of the persons sampled. It was observed in this study that HBsAg was more prevalent among the prisoners within the age groups of 5359 and older than 60 years. This is inconsistent with earlier reports among the general population in Nigeria, Brazil and Ghana which spans the generally accepted sexually active age group of 15-45 years [23]. The difference observed in the present study could be due to the sample size and lowered immunity among the older age groups. There was no significant association between HBsAg prevalence and the ethnic backgrounds of the subjects under study. Furthermore, it was observed that separated inmates from their spouse were more likely to be infected with the HBV when compared to the single or married inmates. This could be attributed to the polygamous practice that is common among people in the study area and the likelihood of separated individuals to be engaged in high risk behaviors including sexual promiscuity. The inmates who attended higher education, Tsangaya education or secondary education were observed to be significantly associated with HBsAg infection than those who had no educational background. This may be as a result of sexually active aged group and they are likely to be exposed in illegal behavior such as sexual promiscuity. Distribution of HBsAg among prison inmates in Borno State in relation to occupation showed higher prevalence rate among civil servants. This may be due to the fewer number of this category of prisoners tested. Higher prevalence of HBsAg was observed in Maiduguri maximum security prison, followed by Biu and Bama medium prison. It is observed in this study that there is significant association of HBsAg prevalence and location of the prison. The higher prevalence found in Maiduguri prison is possibly due to congestion and criminality of inmates with possibility of higher tendency for high risk behavioral practices. Homosexual and length of incarceration are two risk factors observed to be significant in this study. Long period of incarceration is significantly associated with $\mathrm{HBV}$ infection. This is consistent with previous reports from Australia [31], Italy [32], England [33] and Wales [33]. This may be due to the fact that inmates are coming from different locations and ethnic backgrounds and can serve as carriers of the virus and capable of spreading it to their fellow colleagues engaged in practicing high risk behaviors such as homosexuality.

No association was observed between blood transfusion and prevalence of HBsAg. This tally with the reports of Adoga et al. [13] and Adekanle et al. [34] who reported insignificant association of HBV with blood transfusion. The result of the present study however contradicts the report of Agbede et al. [35] who observed significant association between the HBV infection and blood transfusion. Similarly, Intravenous Drug Use (IDU) was not significantly associated with the prevalence of HBsAg among prison inmates in Borno State. This is similar to the report of Abdul et al. [20]. This could be as a result of prohibition of IDU practice among the prison inmates in the study area. In addition, the results of this study did not reveal significant association of this practice with prevalence of HBsAg among prison inmates in Borno State. It may be due to the minimal usage of contaminated sharp objects among the inmates. This is in contrast with the reports of Samuel et al. [36], Ray and Hunter [37], who reported significant association between the sharp objects and infection with the HBV. The present finding could be due to the health awareness and restrictions on the use of sharp objects imposed on the inmates. Poor knowledge of the modes of transmission and spread of HBV infection among the inmates was observed in this study. This agrees with the study of Butler et al. [38] who reported that in Australia there was poor knowledge of hepatitis risk factors among their study subjects. Although most of the inmates in this study had responded yes to having experienced sexually transmitted disease, there was no significant association between this risk factor and prevalence of HBsAg.

\section{Conclusion}

In conclusion, this study has shown that HBV (16.3\%) infection is prevalent among prison inmates in Borno state Nigeria with the females, the elderly ( $>50$ years) and those with higher education having the highest infection rates. Homosexuality and duration of stay under incarceration are the observed risk factors in the transmission of the HBsAg infection among the prison inmates in the study area.

\section{Recommendations}

The following recommendations are:

- The use of other HBV infection serological markers such 
as anti-HBs, anti-HBc, $\mathrm{HBeAg}$, and anti-HBe is advocated in future studies.

- Hepatitis B virus infection continues to be associated with high mortality, morbidity, relapses due to drug resistance and economic burden, hence, there is need to maintain active and continuous surveillance to determine the occurrence and prevalence of the disease for effective formulation of preventive and control measures.

- $\quad$ There is need for Nigerian government to impose a policy that would make screening or test for HBV infection of prisoners prior to incarceration, and vaccinate against the disease. This practice would drastically reduce the rate of spread of infection among inmates and to the general population upon regaining freedom.

\section{References}

1. Ado A, Alhassan S, Chonoko UG, Somalia AU. Seroprevalence of Hepatitis B surface antigen(HBsAg) among Blood donors attending Ahmadu Bello University Teaching Hospital (ABUTH) Zaria Nigeria. Bayero Journal of Pure and Applied Science. 2010; 3: 20-22.

2. Okoye IC, Samba SA. Sero-epidemic Survey of hepatitis B in a population of Northern Nigeria. Animal Research International, 2006; 3: 485-488.

3. Olaitan AO, Zamani LG. Prevalence of hepatitis B virus and hepatitis C virus in ante-natal patients in Gwagwalada- Abuja, Nigeria Report and Opinion (www.sciences.net/report). 2010; 2: 48-50.

4. Forbi JC, Onyemauwa N, Gyar SD, Oyeleye AO, Entonu P, Agwale SM. High Prevalence of Hepatitis B Virus among Female Sex Workers in Nigeria. Rev Inst Med trop S Paulo. 2008; 50: 219-221.

5. Bello RH, Obot E, Olabode HOK. Sero-prevalence and risk factors associated with hepatitis B surface antigen ( $\mathrm{HBsAg}$ ) amongst patients in Biu, Borno State, Nigeria. Journal of Public Health and Epidemiology. 2011; 3: 448-453.

6. World Health Organization (WHO, 2001). Introduction of hepatitis B vaccine into childhood immunization services, Geneva (unpublished document WHO/V\&B/01.31; available on request from Department of Vaccines and Biologicals, World Health Organization, 1211 Geneva 27, Switzerland).

7. Ojo OO, Anibijuwon II. Determination of antibodies to Hepatitis B Virus in pregnant women in Akure, Ondo State, Nigeria. Continental Journal Microbiology. 2009; 3: 6-10.

8. Okafor IN. Incidence of Hepatitis B Virus Infection and Variation. In Serum Alt Levels in HBsAg. Sero-positive and sero-negative individuals in Anambra State, Nigeria. Natural and Applied Sciences Journal. 2011; 12: 71-75.

9. Forbi JC, Iperepolu OH, Zungwe T, Agwale SM. Prevalence of Hepatitis B e Antigen in Chronic HBV Carriers in North-central Nigeria. Journal for Health Population Nutrition. 2012; 30: 377-382.

10. Ataie M, Nokhodian Z, Ataei B, Kassaian N, Yaran M, Hassannejad R. Seroprevalence of hepatitis $B$ virus and human immunodeficiency virus among young prisoners. Journal Research Medicine Sciences. 2013; 18: 70 72.

11. George IO, Ide Y. Hepatitis B virus infection in Nigerian children with sickle cell anaemia, Journal of Medicine and Medical Sciences. 2011; 2: 1213-1215.

12. Bukbuk DN, Bassi AP, Mangoro ZM. Sero-prevalence of hepatitis B surface antigen among primary school pupils in rural Hawul valley, Borno State, Nigeria, Journal Community Medicine and Primary Health Care. 2005; 17: 20-23.

13. Adoga PM, Edmund BB, Joseph CF, Lohya N, Christopher RP, Silas DG et al. Human immunonodeficiency virus, hepatitis B virus and hepatitis C virus: sero-prevalence, co-infection and risk factors among prison inmates in Nasarawa State, Nigeria. Journal of Infectious Diseases. 2009; 3: 539-547.

14. Encyclopedia Britanica. Cambrige University Press. 1998; 4: 265-266.

15. National population commission [NPC]. National population census 2006 results. National Bureau of Statistics. 2006

16. Geological Survey of Nigeria (GSN). The survey of Nigeria's climatic data. Faculty of social and management sciences, University of Maiduguri. 1994; 6: $35-47$.

17. Musa AW, Pindar TY. Geological history of Borno state. Ministry for local government and chieftaincy affairs Algon diary. 2005; 450.

18. Dean AG, Dean JA, Coulombier D, Brendel KA, Smith DC, Burton AH, et al. Epilnfo, version 6: a word processing, database, and statistics program for epidemiology on microcomputers. Centers for Disease. 1995.

19. Hennesey KA, Kim AA, Griffin V, Collins TT, Weinbaum CM, Sabin K. Prevalence with Hepatiti B and C Viruses and Co-Infection with HIV in Three Jails: A case for viral Hepatitis prevention in Jails in the United State. Journal of Urban Health. 2009; 86: 93-105.

20. Abdul MK, Sharaf AS, Cathy AJ, Bryan ES, Sten HV. Risk factors and prevalence of tuberculosis, Human immunodeficiency virus, syphilis, hepatitis $B$ virus and hepatitis $C$ virus among prisoners in Pakistan. International Journals for Infectious Diseases. 2010; 14: 60-66.

21. Dada MO, Akanmu AS, Esan OA. Seroprevalence of HIV and HBV among male prisoners in Lagos State, Nigeria. Nigerian Postgraduate Medical Journal. 2006; 13: 6-9.

22. Haaheim LR, Pattison JR, Whitley RJ. A Practical Guide to Clinical Virology, $2^{\text {nd }}$ ed. University of Bergen, Bergen, Norway. 2002; 179-183.

23. Adjei AA, Armah HB, Gbagbo F, Ampofo WK, Boamah I, Clement AG, et al. Correlates of HIV, HBV, HCV and syphilis infections among prison inmates and officers in Ghana: A national multicenter study. Journal for Infectious Disease. 2008; 8: 41-53.

24. Vassiliki P, Hadjichristodoulou C, Dimitrios C, Theodoridou M. Adherence to the screening program for $\mathrm{HBV}$ infection in pregnant women delivering in Greece. Biomedical Center of Infecious Diseases. 2006; 6: 84.

25. Liao KF, Lai SW, Chang WL, Hsu NY. Screening for viral hepatitis among Male Non-Drug-Abuse prisoners, Scandinavian Journal of Gastroenterology. 2006; 41: 969-973.

26. Abdulelah MA. Hepatitis B Virus. Lecture Note on Power Point Presentation: Department of Nephrology King Khaled University Hospital. 2009.

27. Okwuraiwe AP, Salu OB, Onwuamah CK, Amoo OS, Odunukwe NN, Audu RA. Experience with hepatitis $B$ viral load testing in Nigeria. African Journal of Clinical and Experimental Microbiology. 2011; 12: 101-105.

28. Harry TO, Bajani MD, MosesA E. Hepatitis B virus infection among blood donors and pregnant women in Maiduguri, Nigeria. East Africa Medical Journal. 1994; 70: 596-597.

29. Taura DW, Oyeyi TI, Hafsat MN. Prevalence of hepatitis B surface antigen ( HbsAg) among HIV positive patients attending Aminu Kano Teaching Hospital, Kano, Nigeria. International Journal of Biomedical and Health Sciences. 2008; 4: 33-39.

30. Lawal OA, Bakarey AS, Uche NL, Udeze AO, Okonto OI. HBV infection among intending blood donors who incidentally tested positive to HIV antibody in two Blood Bank in Ibadan, Nigeria. World Applied Sciences Journal. 2009; 7: 1269-1274.

31. Burattini M, Massad E, Rozman M, Azevedo R, Carvalho $H$. Correlation between HIV and HCV in Brazilian Prisoners: evidence for parenteral transmission inside prison. Revista de Saude Publica. 2000; 34: 431-436.

32. Weild AR, Gill ON, Bennett D, Livingstone SJ, Parry JV, Curran L. Prevalence of HIV, hepatitis B, and hepatitis $C$ antibodies in prisoners in England and Wales. Communicable Disease and Public Health Journal. 2000; 3: 121-126.

33. Babudieri S, Longo B, Sarmati L, Starnini G, Dori L, Suligoi B, et al. Correlates of $\mathrm{HIV}, \mathrm{HBV}$, and $\mathrm{HCV}$ infections in a prison inmate population in Italy. Journal of Medical Virology. 2005; 76: 311-317.

34. Adekanle O, Ndububa DA, Ayodeji OO, Paul-Odo B, Folorunso TA. Sexual transmission of the hepatitis B virus among blood donors in a tertiary hospital in Nigeria. Singapore Medical Journal. 2010; 51: 944-947. 
35. Agbede OO, Iseniyi JO, Kolawole MO, Ojuowa A. Risk factors and seroprevalence of hepatitis B surface antigenemia in mothers and their preschool age children in Ilorin, Nigeria. Journal of Therapy. 2007; 4: 67-72.

36. Samuel SO, Aderibigbe SA, Salami TAT, Babatunde OA. Health workers' knowledge, attitude and behavior towards hepatitis B infection in Southern Nigeria. International Journal of Medicine and Medical Sciences. 2009; 1 : 418-424

37. Ray MM, Hunter BD. Seroprevalence of markers for hepatitis B viral infection. International Journal of Infectious Diseases. 2011; 15: 78-121.

38. Butler JG, Dolan KA, Ferson MJ, McGuinness LM, Brown PR, Robertson PW. Hepatitis B and C in New South Wales Prisons: prevalence and risk factors, Medical Journal of Australia. 1997; 166: 127

39. Adjei AA, Armah HB, Gbagbo F, Ampofo WK, Quaye IK, Hesse IF, et al. Prevalence of human immunodeficiency virus, hepatitis $B$ virus, hepatitis $C$ virus and syphilis among prison inmates and officers at Nsawam and Accra, Ghana. Journal of Medical Microbiology. 2006; 55: 593-597.

40. Alter $\mathrm{HJ}$, Blumberg BS. Further studies on a new human isoprecipitin system (Australia antigen), and emerging prevention and control measures. Journa of Viral Hepatitis. 1966; 11: 97-107.

41. Buddeberg F, Schimmer BB, Spahn DR. Transfusion-transmissible infections and transfusion-related immunomodulation. Journal for Science Direct. 2008 22: 503-517.

42. Blumberg BS. Australia antigen and the biology of hepatitis B. virus, Journa of Medical Sciences. 1977; 197: 17-25.

43. Cater VB, Saunders VA. Hepadnavirus and other reverse transcriving DNA viruses. Virology: Principles and Application. School of Biomolecular Sciences, Liverpool John Moores University, UK. 2007; 213-227.

44. Chisari FV, Ferrari C. Viral Hepatitis. Editors. In: Nathanson $\mathrm{N}$ et al. Viral Pathogenesis, Philadelphia, Lippincott-Raven. 1997; 745-778.

45. Coffin CS, Mulrooney PM, van Marle G, Roberts JP, Michalak TI, Terrault NA. Hepatitis B virus (HBV) quasispecies in hepatic and extrahepatic viral reservoirs in liver transplant recipients on prophylactic therapy. Journal of Liver Transplantation. 2011; 17: 955-962.

46. Colin WS, Simard EP, Lyn F, Anthony EF, Beth PB. Hepatitis B Virus Infection: Epidemiology and Vaccination. Oxford Journals Medicine Epidemiologic Reviews. 2006; 28: 112-125.

47. Cusheri A. Acute and chronic hepatitis. Essential surgical practice. $5^{\text {th }}$ edition Oxford University Press. 2002; 334-335.

48. Emechebe GO, Emodi AN, Illechukwu GC, Igwe WC, Ejiofor OS, Illechukwu CA. Hepatitis B virus infection in Nigeria, A Review. Nigerian Medical Journal. 2009; 50: 18-22.

49. European Association for study of the Liver (EASL). International consensus conference on hepatitis B. Geneva, Switzerland Journal Hepatolology. 2002; 38: 533-540.

50. Fairley CK, Read TR. Vaccination against sexually transmitted infections. Current Opinion in Infectious Diseases. 2012; 25: 66-72.

51. Fan YF, Lu CC, Chen WC, Yao WJ, Wang HC, Chang TT, et al. Prevalence and Significance of Hepatitis B Virus (HBV) Pre-S Mutants in Serum and Liver at Different Replicative Stages of Chronic HBV Infection, Journal for hepatology. 2001; 21163: 277-286.

52. Fatima V, Barbara VL, Carlos AV, Adilson JA, Selma AG, Caroline CS Epidemiology and molecular characterization of hepatitis $B$ virus in Luanda, Angola. Memórias do Instituto Oswaldo Cruz. 2010; 105: 970-977.

53. Galibert F, Mandart E, Fitoussi F, Tiollais P, Charnay P. "Nucleotide sequence of the hepatitis B virus genome (subtype ayw) cloned in E. coli”. Nature. 1979; 281: 646-650.

54. Ganem D, Prince AM. Hepatitis B virus infection-natural history and clinical Control and Prevention, Atlanta, Georgia, USA. 2004.

55. Glebe D, Urban S. Viral and cellular determinants involved in hepadnaviral entry. World Journal of Gastroenterology. 2007; 13: 22-38.
56. Harrison T. Desk Encyclopedia of General Virology. Boston: Academic Press. $2009 ; 455$.

57. Herck KV. Prevention of viral hepatitis (B and C) reassessed- campus virtual. Best Practice \& Research Clinical in Gastroenterology. 2008; 22: 1009-1029.

58. Hollinger FB, Liang TJ. Hepatitis B Virus. Editors. In: Knipe DM. et al. Fields Virology, $4^{\text {th }}$ edition. Philadelphia, Lippincott Williams \& Wilkins. 2001; 2971 3036.

59. Hughes RA. Drug injectors and the cleaning of needles and syringes. European Addiction Research. 2000; 6: 20-30.

60. Iannacone M, Sitia G, Isogawa M, Marchese P, Castro MG, Lowenstein PR, et al. Platelets mediate cytotoxic T lymphocyte-induced liver damage. Journal for National Medicine. 2005; 11: 1167-1169.

61. Iannacone M, Sitia G, Ruggeri ZM, Guidotti LG. HBV pathogenesis in animal models: recent advances on the role of platelets. Journal of Hepatol. 2007; 46: $719-726$.

62. Ito K, Kim KH, Lok AS, Tong S. Characterization of genotype-specific carboxyl terminal cleavage sites of hepatitis $B$ virus e antigen precursor and identification of furin as the candidate enzyme. Journal for Virology. 2009; 83: 3507-3517.

63. Jinlin H, Zhihua L, Fan G. Epidemiology and Prevention of Hepatitis B Virus Infection. International Journal Medical Science. 2005; 2: 50-57.

64. Kudesia G, Wreghitt T. Hepatitis B and D viruses (HBV and HDV). In Clinical and Diagnostic Virology, Published in the United States of America by Cambridge University Press, New York, $8^{\text {th }}$ edition. 2009; 32-40.

65. Krugman S. Viral hepatitis, type B. Studies on natural history and prevention re-examined.Yale journal of Biology and Medicine. 1976; 49: 199-203.

66. Leupin O, Bontron S, Schaeffer C, Strubin M. Hepatitis B Virus X Protein Stimulates Viral Genome Replication via a DDB1-Dependent Pathway Distinct from That Leading to Cell Death. Journal of Virology. 2005; 79: 42384245 .

67. Locarnini S. Molecular virology of hepatitis B virus. .Journal for Liver Diseases. 2004; 6: 3-10.

68. Lurman A. Eine icterus epidemic (in German). Berl Klin Woschenschr. 1885; 22: $20-23$.

69. Mani H, Kleiner DE. Liver Biopsy findings in Chronic Hepatitis B. Hepatology. 2009; 49: 61-71.

70. Mahoney FJ, Kane M. Hepatitis B vaccine. In: Plotkin S.A. and Orenstein W.A, (eds). Vaccines, 3rd ed. Philadelphia, W.B. Saunders Company. 1999; 158-182.

71. Messageot F, Salhi S, Eon $P$, Rossignol JM. Proteolytic processing of the hepatitis $B$ virus e antigen precursor. Cleavage at two furin consensus sequences. Journal for Biological Chemistry. 2003; 278: 891-895.

72. Ola SO. Hepatitis B virus infection in the Nigerian health care setting. Faculty lecture series Faculty of Clinical Sciences College of Medicine University of Ibadan Nigeria. 2010

73. Ou JH, Laub O, Rutter WJ. Hepatitis B virus gene function: the precore region targets the core antigen to cellular membranes and causes the secretion of the e antigen. National Journal for Academic Science USA. 1986; 83: 15781582.

74. Petersen N, Barrett B, Maynard A. Hepatitis B surface antigen in saliva, impetiginous lesions, and the environment in two remote Alaskan villages. Applied and Environmental Microbiology. 1976; 32: 572-574.

75. Robinson WS. Hepatitis B viruses. General Features (human). Editors. In: Webster RG, Granoff A. Encyclopedia of Virology. 1994; 554-569.

76. Robinson WS. Hepatitis B virus and hepatitis D virus. Editors. In: Mandell GL, et al. Principles and Practice of Infectious Diseases, $4^{\text {th }}$ edition. New York, Churchill Livingstone. 1995; 1406-1439.

77. Robinson WS. Hepadnavirus (Hepadnaviridae): Hepatitis B virus: General features and Molecular Biolog,. Encyclopedia. 1999; 640-644. 
78. Shi Z, Yang Y, Wang H, Ma L, Schreiber A, Li X, et al. Archives of Pediatrics and Adolescent Medicine 165: 837-846. Singapore Medical Journal. 2011; 51: 947.

79. Tong S, Li J, Wands JR, Wen YM. Hepatitis B virus genetic variants: biological properties and clinical implications, Journal for Emerging Microbes and Infections. 2009; 10: 2-11.

80. Xuanyong Lu. Pathogenesis of Hepatitis B Virus (HBV)-Mediated Liver Injury North American Journal of Medicine and Science. 2011; 4: 1-6.
81. Zuckerman AJ. Hepatitis Viruses. In Baron S, et al., (4 $4^{\text {th }}$ ed) Baron's Medical Microbiology. University of Texas Medical Branch. 1996: 223-228.

82. Zuckerman AJ, Banatvala JE, Schoub BD, Griffiths PD, Mortimer P. Principles and Practice of Clinical Virology, Sixth Edition. Published $2009^{\circ} 2009$ John Wiley \& Sons Ltd. 2009; 283-306. 